\title{
Gender Equality and Economic Diversification
}




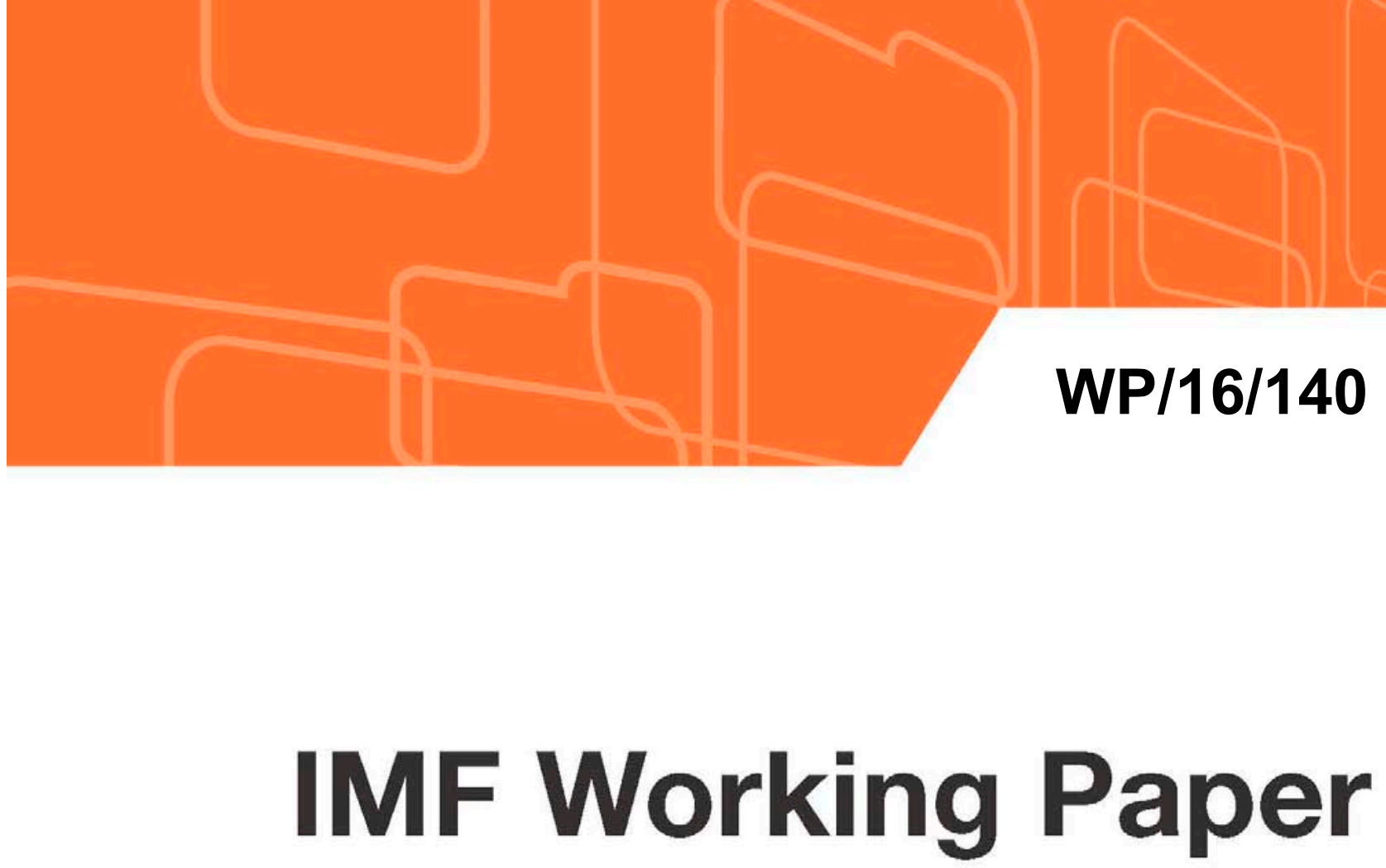

\section{Gender Equality and Economic Diversification}

by Romina Kazandjian, Lisa Kolovich, Kalpana Kochhar, and Monique Newiak

IMF Working Papers describe research in progress by the author(s) and are published to elicit comments and to encourage debate. The views expressed in IMF Working Papers are those of the author(s) and do not necessarily represent the views of the IMF, its Executive Board, or IMF management.

I N T E R N A T I O N A L M O 


\title{
IMF Working Paper
}

\author{
African Department, Human Resource Department, \\ and Strategy, Policy, and Review Department \\ Gender Equality and Economic Diversification ${ }^{1}$ \\ Prepared by Romina Kazandjian, Lisa Kolovich, \\ Kalpana Kochhar, and Monique Newiak \\ Authorized for distribution by Kalpana Kochhar
}

July 2016

\section{IMF Working Papers describe research in progress by the author(s) and are published to elicit comments and to encourage debate. The views expressed in IMF Working Papers are those of the author(s) and do not necessarily represent the views of the IMF, its Executive Board, or IMF management.}

\begin{abstract}
We show that gender inequality decreases the variety of goods countries produce and export, in particular in low-income and developing countries. We argue that this happens through at least two channels: first, gender gaps in opportunity, such as lower educational enrollment rates for girls than for boys, harm diversification by constraining the potential pool of human capital available in an economy. Second, gender gaps in the labor market impede the development of new ideas by decreasing the efficiency of the labor force. Our empirical estimates support these hypotheses, providing evidence that gender-friendly policies could help countries diversify their economies.
\end{abstract}

JEL Classification Numbers: J7, J16, I24, J24, O11, O15.

Keywords: Gender inequality, female labor force participation, economic diversification, economic growth, human capital, low-income and developing countries.

Author's E-Mail Address:

rkazandjian@imf.org, 1kolovich@imf.org, kkochhar@imf.org, mnewiak@imf.org

\footnotetext{
${ }^{1}$ This paper is part of a research project on macroeconomic policy in low-income countries supported by the U.K.'s Department for International Development (DFID), and it should not be reported as representing the views of the International Monetary Fund or of DFID.
} 


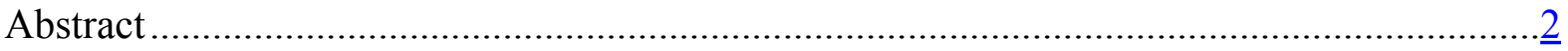

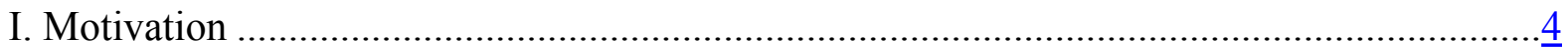

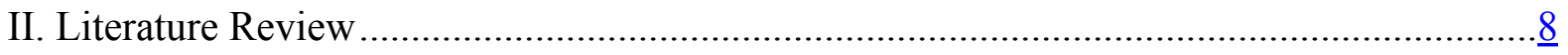

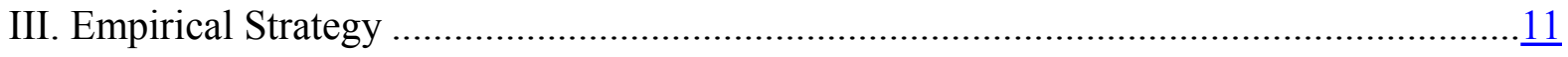

IV. Results: Gender Inequality Impedes Diversification .............................................13

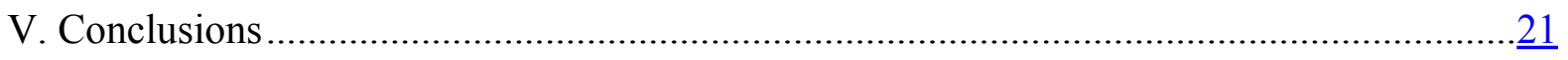

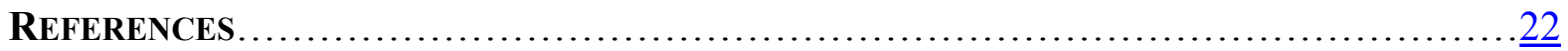

TABLES

Table 1. Explaining Export Diversification .........................................................

Table 2. Explaining Output Diversification ...............................................................

Table 3. Explaining Export Diversification - Dimensions of Gender Inequality...................18

Table 4. Explaining Output Diversification - Dimensions of Gender Inequality ...................19

Table 5. Explaining Diversification - Instrumental Variable GMM ...................................

\section{FIGURES}

Figure 1. Export Product Diversification and Output Growth, 1962-2010 .......................... 4

Figure 2. Export Diversification and Output Volatility, 1962-2010.................................... 4

Figure 3. Export Diversification and Gender Inequality, 1990-2010 ................................... $\underline{6}$

Figure 4. Output Diversification and Gender Inequality, 1990-2010 .................................

\section{BOXES}

Box 1. Defining Export and Output Diversification and Gender Inequality .........................

\section{APPENDIXES}

Annex I: Summary Statistics 


\section{Motivation}

1. The recent decline in commodity prices is a powerful reminder for countriesespecially those rich in resources - to diversify their output and export bases. The drop in oil and other commodity prices in recent years puts substantial pressure on many resourceintensive countries, with growth declining in many of them, and significant macroeconomic adjustment needs arising since export and fiscal revenues have declined markedly (IMF 2016). While oil prices have increased somewhat from their low of less than 30 USD/barrel in early 2016, they are still significantly lower than their peak 2013 levels. Commodity prices more generally are expected to remain at only a fraction of their high levels in the medium term. As a result, reforms to stimulate product and export diversification have gained renewed importance on policy makers' agendas, in particular in resource-intensive economies.

2. Indeed, a substantial body of the literature has highlighted economic diversification as a driver of sustainable growth at the early stages of development (Figures 1 and 2). A long-held tenet of international trade, Ricardo's theory of comparative advantage promotes the idea that countries should specialize in the production of goods and services they can produce at lower relative opportunity cost. Historically, many low-income countries have relied on relatively few trading partners and specialized in commodity and primary products, mainly due to their resource endowments, as might be predicted by the Heckscher-Ohlin model. Yet, as many countries have experienced, even in the current episode of lower commodity prices, the lack of diversification is associated with both lower economic growth and higher volatility. The literature has now well established that diversification and structural transformation - the continued, dynamic reallocation of resources to more productive sectors and activities - are associated with economic growth, particularly at the early stages of development (IMF 2014a; Papageorgiou and

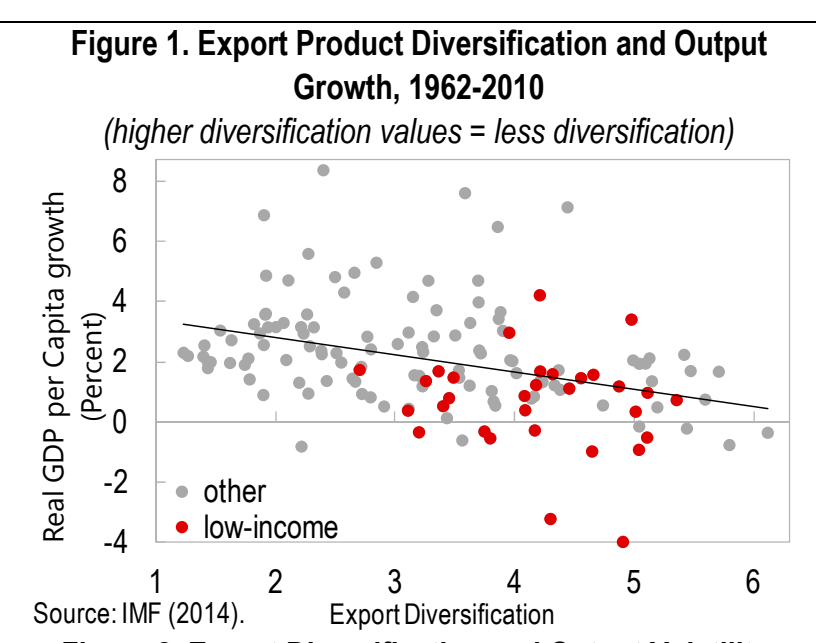

Figure 2. Export Diversification and Output Volatility, 1962-2010

(higher diversification values $=$ less diversification, volatility $=$ standard deviation over 1962-2010)

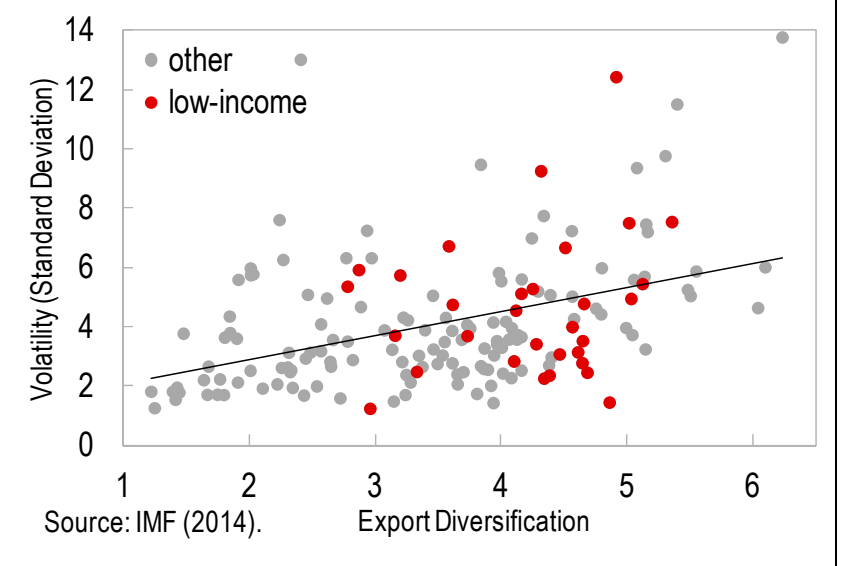


Spatafora 2012). ${ }^{2}$ Given this particular importance of diversification at earlier stages of development, this paper focuses in particular on low-income and developing countries, while also examining a larger set of countries.

3. Several structural country characteristics and policies have been shown to be associated with economic diversification, with education taking on a prominent role. IMF (2014b) highlights a range of country characteristics and policies, such as the level of development, institutional quality, stronger infrastructure, and a higher degree of globalization being strongly associated with diversification. In addition, it confirms the results of other studies that have shown a well-educated workforce matters not only for diversification, but also is strongly associated with export quality upgrading (IMF 2013; IMF 2014b). Increasing human capital accumulation fosters economic diversification by promoting the development of skill-intensive industries and new technologies and by facilitating technological diffusion between firms (Bal-Gunduz and others 2015). Whereas primary and secondary education can enable a country to imitate frontier technology, tertiary education can increase its possibility of innovating (Aghion and Howitt 2006).

4. Building on this literature, we introduce gender equality as an additional determinant of economic diversification with two main hypotheses:

- $\quad$ First, gender gaps in opportunity, such as in education, harm diversification directly by constraining the potential pool of human capital. In particular, in countries where girls' education lags that of boys, female human capital cannot accumulate optimally, therefore slowing down technology adoption and innovation ("human capital channel").

- $\quad$ Second, gender gaps impede the development of new ideas indirectly by decreasing the efficiency of the labor force. Gender gaps in labor force participation shrink the pool of talent from which employers can hire and limit the number of female entrepreneurs (Cuberes and Teignier 2014a; Esteve-Volart 2004; Christiansen and others 2016a; Christiansen and others 2016b). This limitation, in turn, impedes a country's ability to create and execute ideas, i.e. to diversify ("resource allocation channel").

5. In fact, a look at the data shows that gender inequality and economic diversification indeed appear to be inter-linked phenomena (Figures 3 and 4). High levels of gender inequality, as measured by an extended version of the United Nations' Gender Inequality Index, are associated with lower levels of export diversification (a combined measure of export product variety and equality in export shares), while they are negatively related with output diversification (a measure of equality in contribution of sectors to real

\footnotetext{
2 The process of structural transformation is characterized by two dimensions: horizontal (across sectors) and vertical (within a sector). Diversification into new higher value-added sectors is the horizontal dimension. Quality upgrading is the vertical dimension and focuses on producing higher quality (and generally higher priced) products within existing sectors (IMF 2014).
} 
output, including services) mainly in low-income and developing countries. Box 1 describes these indices in more detail.

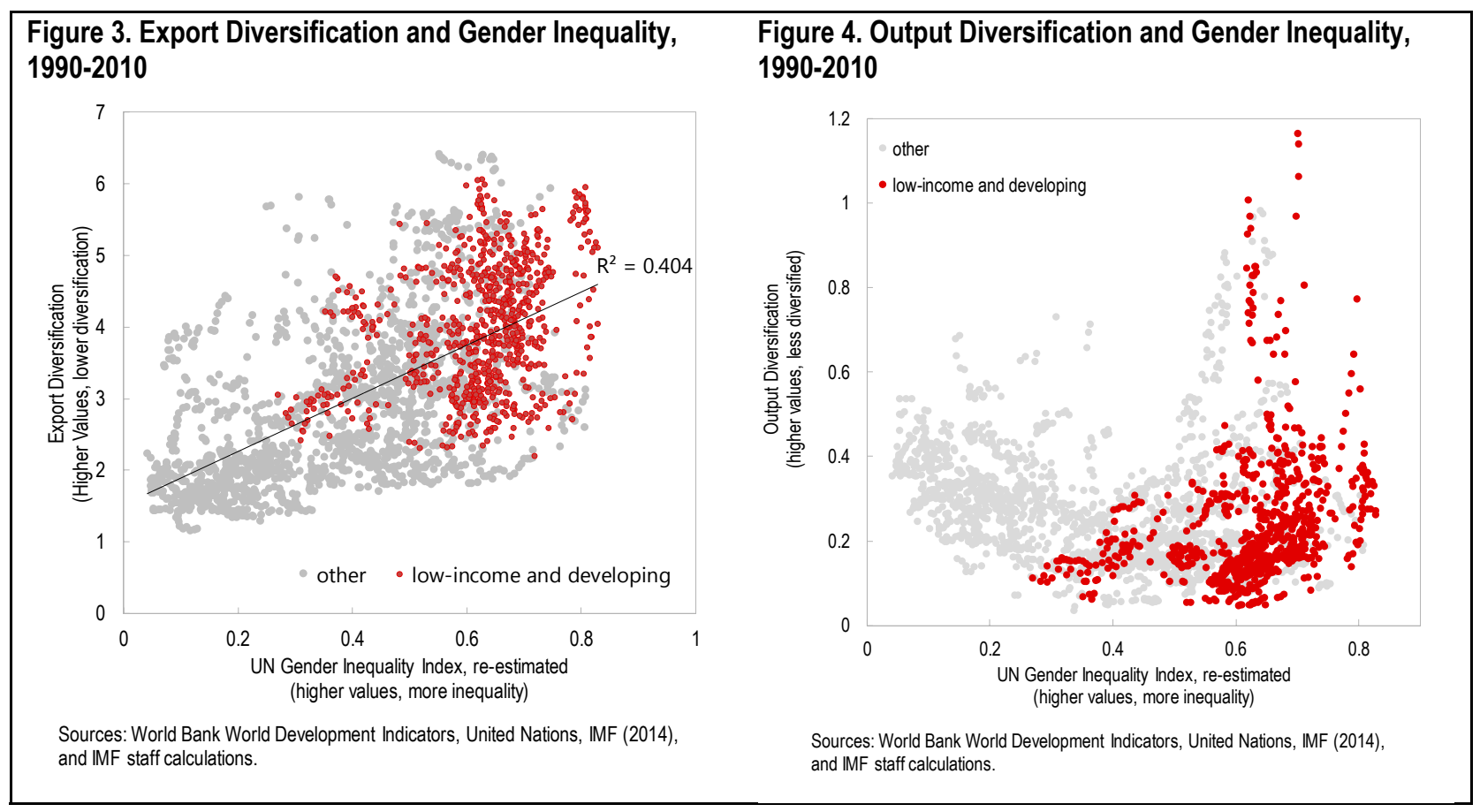

6. Our empirical analysis shows that gender inequality in opportunities and in the labor market is associated with lower diversification. In particular, the contribution of this paper is three-fold:

- $\quad$ First, we present empirical evidence that gender inequality is negatively associated with both output and export diversification in low-income and developing economies. The effect of gender inequality on economic diversification comes on top of the effect of the standard drivers of diversification identified in the literature. While the negative effects of gender inequality and the positive effects of diversification on economic growth have found support in these two separate literatures, to our knowledge, the connection between them has not yet been established.

- Second, our results suggest that both inequality of opportunities and lower female labor force participation are associated with lower economic diversification. These findings support our two main hypotheses. The negative relationship between inequality of opportunity and diversification supports the hypothesis of the human capital channel, while the association between female labor force participation and diversification supports the premise of the resource allocation channel, which reduces the creation of ideas and development of sectors.

- $\quad$ Third, we provide evidence on causality. Gender inequality and diversification are interlinked phenomena and, as described in more detail in Section II, the literature so 
far has mainly focused on how structural transformation coincides with episodes of improvements in gender equality (Akbulut 2011; Olivetti and Petrongolo 2014; Ngai and Petrongolo 2014; Rendall 2013). The novel aspect of our paper is to examine whether gender inequality affects diversification and address endogeneity concerns in our regressions.

7. The paper proceeds as follows. Box 1 highlights the development in some of the key indicators of gender inequality and relates them to measures of economic diversification. Section II provides a brief overview of the literature. Section III presents the more technical details on the empirical strategy and data. Section IV highlights the paper's main results and Section V concludes.

\section{Box 1. Defining Export and Output Diversification and Gender Inequality}

Export product diversification. We use the Theil index of export diversification from IMF (2014b) which follows Cadot and others (2011). The index can be decomposed into a "between" and a "within" sub-index:

$$
\begin{gathered}
\text { Theil Index }=\frac{1}{N} \sum_{i}^{N} \frac{\text { Export Value }_{i}}{\text { Average Exp. Value }} \cdot \ln \frac{\text { Export Value }_{i}}{\text { Average Exp. Value }} \\
=\text { Theil }_{\text {between }}+\text { Theil }_{\text {within }},
\end{gathered}
$$

in which $i$ is the product index and $N$ the total number of products. The "between" Theil index captures the extensive margin of diversification, i.e. the number of products, while the "within" Theil index captures the intensive margin (product shares). Lower values of the Theil index indicate higher levels of export product diversification. The index is available for 188 countries from 1962-2010.

Output diversification. As services are not included in the calculation of export product diversification, we additionally use the output diversification Theil index in our regressions to account for the impact of changes in the service sector. Following the methodology used for the export Theil index described above, the output diversification index was constructed for the real subsectors from the UN's sectoral database in IMF (2014b). The index covers 188 countries from 1970-2010.

Gender Inequality Index (GII). The gender inequality index is the extended version of the United Nations Gender Inequality Index (Gonzales and others 2015b; Stotsky and others 2016), which captures gender inequality across areas of health (maternal mortality ratios and adolescent fertility rates), empowerment (share of parliamentary seats and education attainment at the secondary level for both males and females), and labor force participation (rates by sex). While the GII has drawbacks (such as a complicated functional form and a combination of indicators that compare men and women with indicators that pertain only to women), it is preferable to alternatives such as the GDI (in which one of the main components is not observed and is imputed). The index spans values between 0 and 1 , with higher values indicating higher gender inequality. The index is available for 141 countries from 1990-2013. 


\section{Literature REVIEW}

8. Diversification, development, and growth are closely interlinked, in particular in low-income countries.

- Despite significant cross-country heterogeneity, greater diversification has been associated with improved macroeconomic performance: higher growth, reduced volatility, and increased resilience to external shocks (Koren and Tenreyro 2007; Cadot and others 2011). Singer (1950) demonstrated that a country's initial level of diversification is positively correlated with economic growth. Using an Instrumental Variable Bayesian Model Averaging approach to move beyond correlations, IMF (2014a) finds that for low-income countries, extensive diversification (introducing new product lines), intensive diversification (creating a more balanced mix of existing products), and the broader process of output diversification are indeed drivers of economic growth. Diversification also involves shifting resources from sectors with high volatility, such as mining and agriculture, to sectors with less volatility, such as manufacturing, resulting in greater stability. Countries with more diversified production structures tend to have lower volatility of output, consumption, and investment (Moore and Walkes 2010; Mobarak 2005).

- $\quad$ There is a non-linear relationship between diversification and development (Imbs and Wacziarg, 2003). As countries develop, they diversify until they reach a critical point. Beyond this point, they start specializing in low-volatility sectors (Imbs and Wacziarg, 2003; Koren and Tenreyro 2007; Cadot and others 2011).

9. The literature also documents a negative link between real GDP per capita growth and gender inequality (Elborgh-Woytek and others 2013). On a macro level, the relationship between gender inequality and economic growth has been a topic of increasing interest in the academic and policy literature in recent decades. Dating back to the early 1990s, a special issue of World Development was dedicated to introducing a gender lens to macroeconomics (Cagatay and others 1995). Since then, a broad literature has developed on the topic of gender inequality and its connection to economic development and growth (see, e.g., the World Bank's 2012 World Development Report: Gender).

10. Economic development has been shown to decrease gender inequality, while persistent discrimination against women can adversely affect development (Goldin 1994; Hill and King 1995; Dollar and Gatti 1999; Tzannatos 1999; Stotsky 2006; Cuberes and Teignier 2014b). Whereas our paper focuses on the latter direction of causality, many others have explored the former (e.g. Galor and Weil 1996; Fernandez 2007; Alesina and others 2011; Duflo 2012 for both directions). The following results demonstrate some of the channels through which gender inequality can negatively impact macroeconomic performance:

- $\quad$ Education. Studies have confirmed the negative effect of gender inequality in education on growth (Hill and King 1995; Engelbrecht 1997; Forbes 1998; Dollar and Gatti 1999; Klasen 1999; Knowles and others 2002; Klasen and Lamanna 2009; Seguino 2010). Dollar and Gatti (1999) find that gender inequality in education 
negatively impacts growth in countries where female educational attainment is high. Klasen (1999) demonstrates that the negative effect is present in all economies. ${ }^{3}$ Berge and Wood (1994) provide support for the hypothesis that an educated female labor force is a determinant of manufacturing exports growth. Using broader measures of gender inequality going beyond education gaps, a recent study by Amin and others (2015) confirms their strong negative impact on economic growth but only in poor countries.

\section{We hypothesize that these negative effects of gender inequality in educational opportunities affect growth at least in part by obstructing the economic diversification process.}

- Occupation. Occupational choice models are based on the assumption that men and women have the same distribution of talent (Cuberes and Teignier 2012; EsteveVolart 2004). Gender gaps in entrepreneurship distort the efficient allocation of talent (Cuberes and Teignier 2012). As a certain percentage of women are prevented from becoming entrepreneurs, they are forced to work as employees thus increasing the supply of labor. As a result, equilibrium wages and aggregate productivity fall. Gender gaps in labor force participation are modeled as preventing a fraction of women from supplying labor to the market, hence decreasing income per capita. Cuberes and Teignier (2014a) present an updated version of the model in which women also have the choice to become self-employed, in addition to being entrepreneurs and workers. In this version of the model, women face two additional exogenous restrictions: only a fraction can become self-employed and those who become workers receive lower wages than men. The main results are not qualitatively different. Esteve-Volart (2004) makes explicit the negative endogenous effect of gender gaps in education on growth: the suboptimal allocation of managerial talent explicitly leads to lower female human capital accumulation and thus slower technology adoption and innovation, which reduces aggregate output and obstructs economic growth. The negative effects of gender discrimination in managerial talent allocation are more serious for sectors where high-level skills are needed, such as the non-agricultural sector, whereas restricted female labor force participation in general impacts all sectors, including agriculture. Finally, using a model of endogenous savings, fertility, and labor market participation, Cavalcanti and Tavares (2016) show that an increase of 50 percent in the gender wage gap could lead to a decrease in income per capita by 35 percent.

\footnotetext{
${ }^{3}$ Earlier studies have shown somewhat different results: Barro and Lee (1994) and Barro and Sala-i-Martin (1995) find that female secondary education has a negative impact on growth, as low female educational attainment signifies "backwardness" and hence higher growth potential. Klasen (1999) and Lorgelly and Owen (1999), however, suggest that the finding may reflect multicollinearity problems resulting from the inclusion of both female and male education variables in the regression analysis and the disproportionate influence of a few outlier countries.
} 
We explore whether the channels posited in these models affect growth via their effects on the dynamic process of diversification and structural transformation of the economy.

- $\quad$ Aggregate measures of gender inequality and growth. Recent empirical evidence, using an extended version of the UN's Gender Inequality Index (GII), shows that several dimensions of gender inequality are strongly associated with lower growth, in particular in low-income countries (Gonzales and others 2015b; Hakura and others 2016).

In this paper, we test whether measures of gender inequality are also related to lower export and output diversification.

- $\quad$ Gender wage inequality has had a positive effect on export-led growth in semiindustrialized export-oriented economies, while it has had a negative effect in lowincome agricultural countries (Seguino 2010). On the other hand, accounting for the different productivity of male and female workers, Schober and Winter-Ebmer (2011) do not find support for the hypothesis that increased gender inequality contributes to growth but argue that it may indeed hamper it.

Due to the lack of extensive and reliable data on wage inequality in low-income and developing countries, in this paper, we focus instead on gender inequality in reproductive health, empowerment, and labor market participation, the subcomponents of the multi-dimensional GII.

11. Structural transformation has been shown to coincide with episodes of decreases in gender inequality, in particular in the service sector. Several studies examine the relationship between women's economic participation and structural transformation, and have focused predominantly on the influence of the service sector (Akbulut 2011; Olivetti and Petrongolo 2014; Ngai and Petrongolo 2014; Rendall 2013). Rendall (2013) finds that structural transformation has been important in reducing gender inequality and argues that this has happened by decreasing the labor demand for physical ("brawn") attributes. Economies with lower "brawn" requirements offer better labor market opportunities because they allow women to take advantage of their comparative advantage in less physical ("brain") attributes. For example, in Mauritius, the development of the textile industry coincided with an increase in female labor force participation of nearly 60 percent between 1983 and 1999 (Svirydzenka and Petri 2014). Cavalcanti and Tavares (2007) link increases in female labor force participation to increases in government expenditures, leading to higher demand for services provided by the government. This in turn further encourages female labor force participation, especially when the public sector typically employs more women.

These studies emphasize the direction of causation from structural transformation of the economy to women's economic participation. The novelty of our paper is exploring the reverse relationship, namely whether greater gender equality can enhance and support the process of structural transformation. 
12. Gender-based legal restrictions exert a significant impact on women's economic participation. Restrictions to participation have been shown to negatively affect women's access to finance (Demirgüç-Kunt and others 2013), employment (Amin and Islam 2014), labor force participation (Gonzales and others 2015b), asset ownership and wealth (Deere and others 2013), property rights (Razavi 2003), and adoption of new technologies (Quisumbing and Pandofelli 2010). A recent IMF study uses the comprehensive database compiled in the World Bank's Women, Business and the Law Report (World Bank 2013; World Bank 2015) to demonstrate that restrictions on women's rights to inheritance and property, as well as legal impediments to economic activity, such as the right to open a bank account or to freely pursue a profession, significantly exacerbate gender gaps in labor force participation (Gonzales and others 2015a).

Our study uses the results from this stream of the literature to argue that gender-based legal restrictions are valid instruments to tackle endogeneity concerns in the analysis of the impact of gender inequality on diversification: legal restrictions exacerbate gender inequality, which, in turn, impedes output and export diversification.

\section{To our knowledge, there are no theoretical studies on the impact of gender} inequality in opportunities and outcomes on output and export diversification. Most theoretical studies of the impact of gender inequality on growth have examined the causal channels of fertility and the education of children (Galor and Weil 1996; Lagerlöf 2003; Cavalcanti and Tavares 2016; Doepke and Tertilt 2008; Agenor and others 2010). Hence, the empirical investigation in this study is broadly based on the theoretical occupational choice models of Cuberes and Teignier (2012) and Esteve-Volart (2004), which examine the effects of gender discrimination on aggregate output and economic growth.

We explore whether the channels posited in these models are similarly at play concerning the process of diversification of the economy.

\section{EMPIRICAL STRATEgY}

14. We analyze the effect of gender inequality on diversification together with determinants previously highlighted in the literature. To obtain unbiased estimates, we control for unobservable variables that differ across countries, as well as common effects over time in the following relationship for the period 1990-2010 in our baseline estimations:

$$
\begin{gathered}
\text { Diversification }_{i t}=\beta_{1} \text { Gender Inequality }_{i t}+\beta_{2} \text { GenderInequality }_{i t} \cdot \text { LIDC }+ \\
\gamma^{\prime} \text { Structural Characteristics }_{i t}+\delta^{\prime} \text { Policies }_{i t}+\varphi^{\prime} \text { Institutions }_{i t}+ \\
+\tau^{\prime} \text { Cyclical Factors }_{i t}+\mu_{i}+\theta_{t}+\varepsilon_{i t},
\end{gathered}
$$

in which

- $\quad$ Diversification $_{i t}$ represents the measure of either export or output diversification as defined in Box 1 for country $i$ at time $t$. 
- $\quad$ The main contribution of our paper is to test whether gender inequality exhibits a significant effect on diversification. Gender Inequality $y_{i t}$ tests for this effect at two levels: first, to account for the combined effect of several dimensions of gender inequality, we use the extended version of the United Nations Gender Inequality Index, i.e. a combination of gaps in labor force participation, education, and reproductive health, as well as female seats in parliaments as described earlier in Box 1. In a second step, to test for the effect of individual measures of gender inequality, the index is replaced by the female-to-male gross enrollment ratio in secondary school, the female labor force participation rate, the share of female seats in parliament, the adolescent fertility rate, and the risk of maternal death. As the relationship between diversification and gender inequality may vary across levels of development, we include a low-income and developing country interaction term $(L I D C)$ in our main regressions.

- $\quad$ Structural Characteristics it may significantly impact a country's ability to diversify. We therefore include real GDP per capita and its square in the regression to account for the overall level of development, as well as the turning point after which countries re-concentrate their export or output structure (IMF 2014b; Dabla-Norris and others 2013). The baseline regressions also include population size to capture the pool of workers potentially able to produce different products in a country, along with an index of human capital to account for a country's ability to generate and implement new ideas. In addition, we test whether being resource-rich exhibits a negative effect on diversification by introducing the share of mining in GDP or the share of fuel exports into the regressions.

- Institutions It $_{\text {it }}$ shape the environment in which businesses operate and the ease of entering a market to implement an idea or to produce a new product. To account for this impact, our regressions use both general institutional quality (e.g. Frasier Institute Summary Index), as well as specific dimensions of the regulatory environment (e.g. legal systems and property rights).

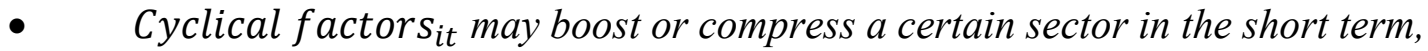
therefore impacting diversification over time. We therefore introduce macroeconomic variables, such as terms-of-trade, real effective exchange rates, and real GDP growth into our regressions.

- $\quad$ Policies $_{i t}$ may foster economic diversification. Here, we test for several policy dimensions, such as more openness to trade (through an index of globalization, the degree of freedom to trade internationally, and average tariff rates), financial development (an index of financial reform, and interest rate controls and private sector credit-to-GDP as robustness checks), the scale of investment in the economy (investment in percent of GDP and per worker), and infrastructure development (density of landlines and length of road network).

- $\quad$ To capture other factors over time and by country we include $\mu_{i}$ and $\theta_{t}$, that is country fixed effects and time fixed effects into our baseline regressions. $\varepsilon_{i t}$ represents the error term. 
Please see Annex I for detailed summary statistics of the variables.

15. In addition to the fixed effects specifications, we address the endogenous relationship between economic diversification and gender inequality by using the instrumental variable generalized method of moments (IV-GMM) technique. ${ }^{4}$ Gender inequality in outcomes and opportunities may cause lower levels of export and output diversification, but lower levels of diversification may lead to larger gender inequalities in outcomes and opportunities. Therefore, to determine the direction of causality, we use IVGMM in addition to the fixed effects specifications as highlighted above. ${ }^{5}$ In particular, the instrumental variables (IV) approach isolates the causal effect of the country-specific degree of gender inequality, as measured by the GII, on export and output diversification.

16. We introduce legal rights for women as instruments into our specifications. To be valid, an instrument needs to fulfill two criteria: i) not have a direct impact on export and output diversification (be uncorrelated with the error term of the regression) and ii) be highly correlated with gender inequality, the endogenous regressor of interest. Similar to the institutions and growth literature, we draw from a large dataset of legal restrictions on women's economic activity. We argue that gender-based legal restrictions - the mere existence of laws on the books of a country - do not exert a direct impact on export and output diversification, thus fulfilling the first condition of exogeneity, which we confirm with the Hansen statistical test. As argued in the previous section, legal rights have been shown to have a direct and strong impact on gender inequality, supported by various strands of the literature, which makes them good candidates to fulfill the second condition of relevance of the instrument in theory and which we also confirm in the next section.

\section{RESULTS: GENDER INEQUALITY IMPEDES DIVERSIFICATION}

17. We find that gender inequality is strongly and negatively associated with export diversification in low-income and developing countries, even after accounting for the other drivers of diversification discussed earlier. Table 1 presents our baseline regressions which includes time and country fixed effects along with a large set of structural country characteristics, policies, and cyclical factors. In particular, we find the following:

- $\quad$ Gender inequality, as measured by the extended version of the UN's Gender Inequality Index, is strongly associated with export diversification. In particular, moving from a situation of absolute gender inequality to perfect gender equality measured by the index could decrease the Theil index of export diversification, i.e. increase export diversification in low-income and developing countries, by 0.6 to 2 units. The magnitude of this effect is equivalent to up to about two standard deviations of the index across low-income and developing countries. Looking beyond low-income and developing countries, the results show that higher levels of gender

\footnotetext{
${ }^{4}$ See Bandiera and Natraj (2013) for a discussion of panel regressions and the endogenous relationship between gender inequality and growth.

${ }^{5}$ All regressions are estimated using heteroskedasticity-robust Huber-White standard errors.
} 
inequality are significantly associated with lower levels of export diversification across all levels of development.

- $\quad$ The effect of gender inequality comes on top of structural characteristics previously highlighted in the literature. Our results confirm the U-shaped relationship between export diversification and development (Dabla-Norris and others 2013) in which countries diversify until they reach a certain level of development but re-concentrate afterwards. A higher share of mining in output is associated with a less diversified export base. In line with a larger pool of talent, population size (in most of our specifications) and human capital (in some specifications) are associated with higher export diversification.

- $\quad$ The impact of gender inequality remains when controlling for policies associated with export diversification. In particular, we show that institutions - creating a better business environment, e.g. as measured by the Frasier Summary Index of Institutions or legal systems and property rights - are significantly and positively associated with higher levels of diversification. A higher degree of openness in international trade expands the possible pool of trading partners and demand for exports, and our results confirm a positive and significant relationship with export diversification. Finally, better infrastructure is also strongly associated with higher degrees of export diversification.

- $\quad$ Finally, macroeconomic factors also appear to play a role. Real exchange rate appreciation and terms-of-trade improvement are associated with lower degrees of export diversification, possibly reflecting the effect of lower price competitiveness in the short term and higher quantities of exports of main sectors when their prices are high. ${ }^{6}$

\section{Gender inequality is negatively associated with output diversification in low-} income and developing countries. To capture the role that the service sector may play in the economy, we examine output diversification in a similar empirical setup. The results for structural characteristics and policies are broadly comparable to the ones on export diversification described above. We find that gender inequality in low-income and developing countries is negatively associated with output diversification in all our specifications. However, we find mixed results on gender inequality for the remainder of countries. There is a significant and positive association of gender inequality and output diversification in some of the regressions for these countries, likely reflecting the fact that low gender inequality may result in greater participation of women in the service sector, in which countries tend to re-concentrate production as they develop.

\footnotetext{
${ }^{6}$ The results hold when real GDP per capita growth is used as an alternative to capture cyclical components. Several measures of income inequality were included in the regressions but did not yield significant results.
} 


\begin{tabular}{|c|c|c|c|c|c|c|c|c|c|}
\hline \multicolumn{10}{|c|}{ Table 1. Explaining Export Diversification } \\
\hline & (1) & (2) & (3) & (4) & (5) & (6) & (7) & (8) & (9) \\
\hline \multicolumn{10}{|l|}{ Gender Inequality } \\
\hline Gender Inequality Index & $\begin{array}{l}0.703^{* *} \\
(0.273)\end{array}$ & $\begin{array}{l}0.752^{* * *} \\
(0.278)\end{array}$ & $\begin{array}{c}0.776^{* * *} \\
(0.277)\end{array}$ & $\begin{array}{c}1.156^{* \star *} \\
(0.319)\end{array}$ & $\begin{array}{c}1.141^{* * *} \\
(0.284)\end{array}$ & $\begin{array}{l}1.381^{* * *} \\
(0.282)\end{array}$ & $\begin{array}{l}1.078^{\star \star \star} \\
(0.294)\end{array}$ & $\begin{array}{c}0.983^{* * *} \\
(0.298)\end{array}$ & $\begin{array}{l}0.665^{\star *} \\
(0.264)\end{array}$ \\
\hline-- in LIDC & $\begin{array}{l}1.014^{* *} \\
(0.431)\end{array}$ & $\begin{array}{l}0.983^{* *} \\
(0.438)\end{array}$ & $\begin{array}{l}1.113^{* *} \\
(0.435)\end{array}$ & $\begin{array}{c}0.338 \\
(0.457)\end{array}$ & $\begin{array}{l}0.880^{* *} \\
(0.432)\end{array}$ & $\begin{array}{c}0.120 \\
(0.440)\end{array}$ & $\begin{array}{c}0.274 \\
(0.405)\end{array}$ & $\begin{array}{c}0.538 \\
(0.417)\end{array}$ & $\begin{array}{c}0.630 \\
(0.426)\end{array}$ \\
\hline \multicolumn{10}{|l|}{ Structural Factors } \\
\hline Log(Population) & $\begin{array}{c}-0.707^{\text {***}} \\
(0.133)\end{array}$ & $\begin{array}{c}-0.560^{* * *} \\
(0.135)\end{array}$ & $\begin{array}{c}-0.568^{* * *} \\
(0.136)\end{array}$ & $\begin{array}{c}-1.059^{* * *} \\
(0.156)\end{array}$ & $\begin{array}{c}-0.434^{* \star *} \\
(0.146)\end{array}$ & $\begin{array}{l}-0.222 \\
(0.145)\end{array}$ & $\begin{array}{c}-0.682^{* * *} \\
(0.138)\end{array}$ & $\begin{array}{c}-0.450^{* * *} \\
(0.148)\end{array}$ & $\begin{array}{l}-0.101 \\
(0.147)\end{array}$ \\
\hline Lag Human capital index & $\begin{array}{l}0.0460 \\
(0.109)\end{array}$ & $\begin{array}{l}0.0406 \\
(0.110)\end{array}$ & $\begin{array}{l}0.0743 \\
(0.110)\end{array}$ & $\begin{array}{l}-0.112 \\
(0.127)\end{array}$ & $\begin{array}{l}-0.0729 \\
(0.111)\end{array}$ & $\begin{array}{l}0.0309 \\
(0.111)\end{array}$ & $\begin{array}{c}-0.286^{* *} \\
(0.116)\end{array}$ & $\begin{array}{c}-0.285^{* *} \\
(0.118)\end{array}$ & $\begin{array}{l}0.0887 \\
(0.103)\end{array}$ \\
\hline Log(Real GDP per capita) & $\begin{array}{c}-1.838^{* * *} \\
(0.294)\end{array}$ & $\begin{array}{c}-2.371^{* * *} \\
(0.289)\end{array}$ & $\begin{array}{c}-1.712^{* * *} \\
(0.308)\end{array}$ & $\begin{array}{l}-0.215 \\
(0.310)\end{array}$ & $\begin{array}{c}-1.736^{\star \star *} \\
(0.297)\end{array}$ & $\begin{array}{c}-0.970^{* * *} \\
(0.311)\end{array}$ & $\begin{array}{c}-1.166^{* * *} \\
(0.296)\end{array}$ & $\begin{array}{c}-1.750^{* \star *} \\
(0.301)\end{array}$ & $\begin{array}{c}-0.971^{* * *} \\
(0.328)\end{array}$ \\
\hline -- squared & $\begin{array}{l}0.114^{* * *} \\
(0.0174)\end{array}$ & $\begin{array}{l}0.140^{* * *} \\
(0.0172)\end{array}$ & $\begin{array}{l}0.103^{* * *} \\
(0.0182)\end{array}$ & $\begin{array}{c}0.0245 \\
(0.0190)\end{array}$ & $\begin{array}{l}0.108^{* * *} \\
(0.0179)\end{array}$ & $\begin{array}{c}0.0605^{* * *} \\
(0.0188)\end{array}$ & $\begin{array}{c}0.0704^{* * *} \\
(0.0178)\end{array}$ & $\begin{array}{l}0.112^{\star \star \star} \\
(0.0182)\end{array}$ & $\begin{array}{c}0.0516^{* * *} \\
(0.0191)\end{array}$ \\
\hline Mining as share of GDP & $\begin{array}{l}0.00937^{* *} \\
(0.00396)\end{array}$ & $\begin{array}{l}0.00694^{*} \\
(0.00398)\end{array}$ & $\begin{array}{l}0.0119^{* * *} \\
(0.00416)\end{array}$ & $\begin{array}{l}0.0253^{* * *} \\
(0.00377)\end{array}$ & $\begin{array}{l}0.00694^{*} \\
(0.00407)\end{array}$ & $\begin{array}{l}0.0119^{* * *} \\
(0.00407)\end{array}$ & $\begin{array}{l}0.0221^{* * *} \\
(0.00392)\end{array}$ & $\begin{array}{l}0.0266^{* * *} \\
(0.00407)\end{array}$ & $\begin{array}{l}0.0236^{* * *} \\
(0.00472)\end{array}$ \\
\hline \multicolumn{10}{|l|}{ Policies } \\
\hline \multicolumn{10}{|l|}{ 1. Institutions } \\
\hline Fraser Institute Sum. Index & $\begin{array}{c}-0.116^{\star * *} \\
(0.0137)\end{array}$ & & & & & & & & $\begin{array}{c}-0.0700^{* * *} \\
(0.0178)\end{array}$ \\
\hline Legal Syst.\& Property Rights & & $\begin{array}{c}-0.0358^{* * *} \\
(0.0102)\end{array}$ & & & & & & & \\
\hline \multicolumn{10}{|l|}{ 2. Openness } \\
\hline Freedom to trade & & & $\begin{array}{c}-0.0646^{* * *} \\
(0.00858)\end{array}$ & & & & & & $\begin{array}{l}-0.0219^{*} \\
(0.0114)\end{array}$ \\
\hline Globalization Index & & & & $\begin{array}{c}-0.0123^{* * *} \\
(0.00268)\end{array}$ & & & & & \\
\hline \multicolumn{10}{|l|}{ 3. Infrastructure } \\
\hline Length of road network & & & & & $\begin{array}{c}-0.0300^{* *} \\
(0.0144)\end{array}$ & & & & \\
\hline Log(landlines/1000 workers) & & & & & & $\begin{array}{c}-0.129^{* * *} \\
(0.0177)\end{array}$ & & & $\begin{array}{c}-0.110^{* * *} \\
(0.0180)\end{array}$ \\
\hline \multicolumn{10}{|l|}{ Macro/Cyclical Factors } \\
\hline Terms of Trade & & & & & & & $\begin{array}{l}0.00313^{* * *} \\
(0.000347)\end{array}$ & & $\begin{array}{l}0.00427^{* * *} \\
(0.000440)\end{array}$ \\
\hline $\log ($ REER) & & & & & & & & $\begin{array}{l}0.186^{\star \star *} \\
(0.0519)\end{array}$ & $\begin{array}{l}0.305^{\star * *} \\
(0.0490)\end{array}$ \\
\hline Constant & $\begin{array}{c}11.90^{* * *} \\
(1.201)\end{array}$ & $\begin{array}{c}13.69^{\star \star *} \\
(1.209)\end{array}$ & $\begin{array}{c}10.78^{* * *} \\
(1.273)\end{array}$ & $\begin{array}{c}5.434^{* * *} \\
(1.209)\end{array}$ & $\begin{array}{c}10.21^{* \star *} \\
(1.232)\end{array}$ & $\begin{array}{c}6.928^{\star * *} \\
(1.284)\end{array}$ & $\begin{array}{c}8.737^{\star \star \star} \\
(1.223)\end{array}$ & $\begin{array}{c}9.483^{\star \star \star} \\
(1.263)\end{array}$ & $\begin{array}{c}5.712^{\star * *} \\
(1.436)\end{array}$ \\
\hline Observations & 1,841 & 1,835 & 1,836 & 1,798 & 1,726 & 1,726 & 1,903 & 1,909 & 1,583 \\
\hline Countries & 100 & 100 & 100 & 105 & 89 & 89 & 100 & 102 & 84 \\
\hline R-squared & 0.181 & 0.141 & 0.174 & 0.108 & 0.110 & 0.136 & 0.127 & 0.118 & 0.271 \\
\hline
\end{tabular}




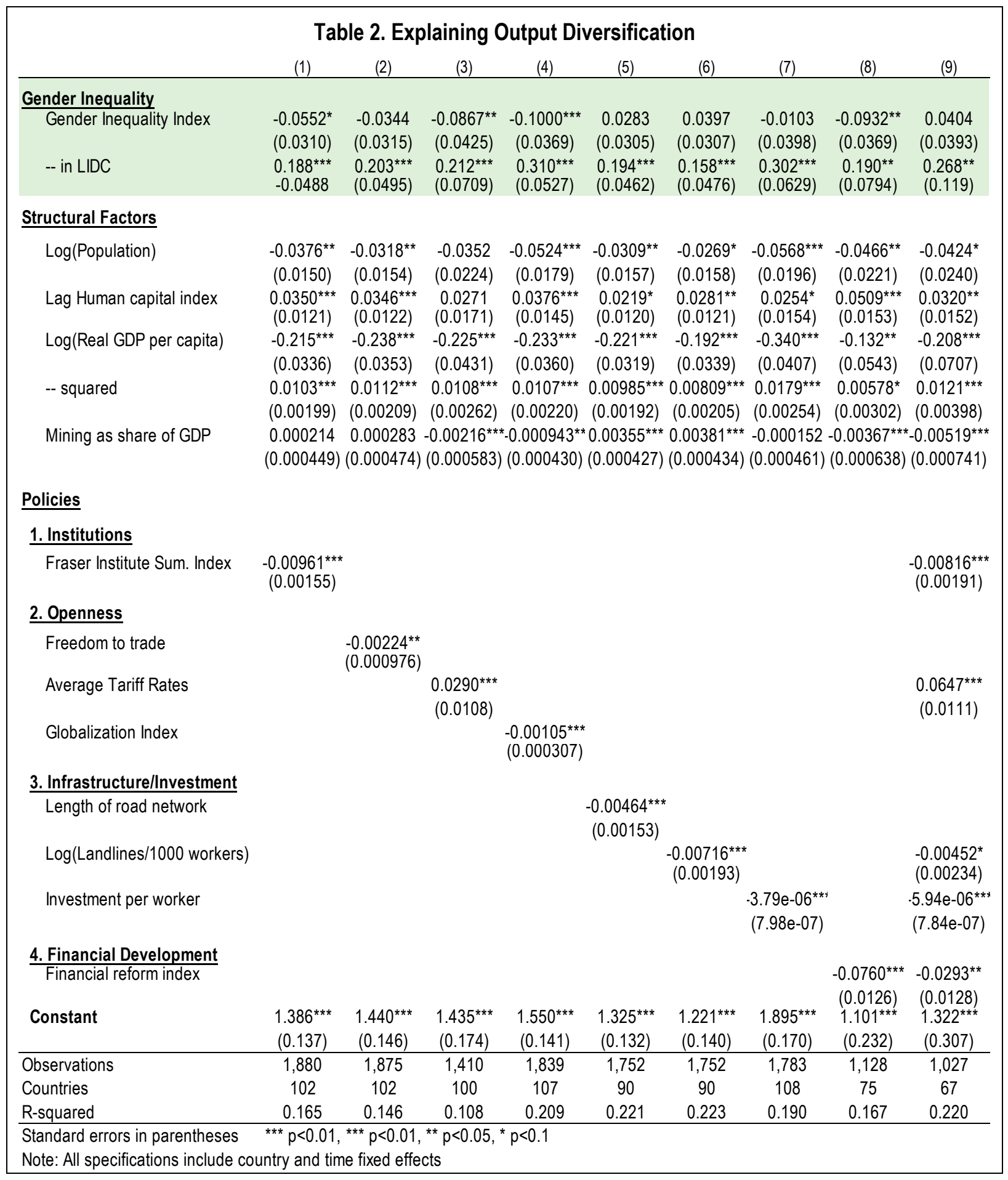

16

CInternational Monetary Fund. Not for Redistribution 
19. In addition, our results provide evidence on two main channels through which gender inequality inhibits economic diversification. To test for the contribution of different dimensions of gender inequality, we include female labor force participation, gender gaps in education, female representation in parliament, and indicators of female health (maternal mortality and adolescent fertility) simultaneously into our regressions. The results in Table 3 highlight that there is some evidence for the human capital channel-a higher female-to-male enrollment ratio is significantly and positively related to export diversification, particularly in low-income and developing countries. In addition, there is evidence for the resource allocation channel, as higher female labor force participation rates are associated with higher export diversification levels in low-income and developing economies. The results also provide some evidence that better health outcomes, in terms of lower maternal mortality ratios and adolescent fertility rates are positively associated with export diversification. Table 4 highlights that the results are broadly similar for output diversification, where higher female labor force participation and higher educational enrollment ratios for girls relative to boys in low-income and developing countries are associated with higher output diversification when controlling for policies and institutions.

20. Finally, we also find evidence for causality in the specifications by instrumenting gender inequality with legal rights. Table 5 highlights gender inequality as a significant determinant of export and output diversification, even after including legal rights for women, such the right to be the head of a household or full community marital property rights, as instruments for gender inequality in GMM regressions. The instruments we use pass standard econometric and rule-of-thumb tests. Each of the instruments is individually significant in the first-stage regressions and the F-statistics of the IV regressions are well above the rule-ofthumb threshold value of 10. In addition, in specifications with two or more instruments, the p-values of the Hansen J-statistic do not allow us to reject the joint null hypothesis that the instruments are uncorrelated with the error term, supporting our hypothesis that the excluded instruments are indeed correctly excluded from the estimated equation. These results suggest that gender inequality may be indeed a cause of lower economic diversification. 


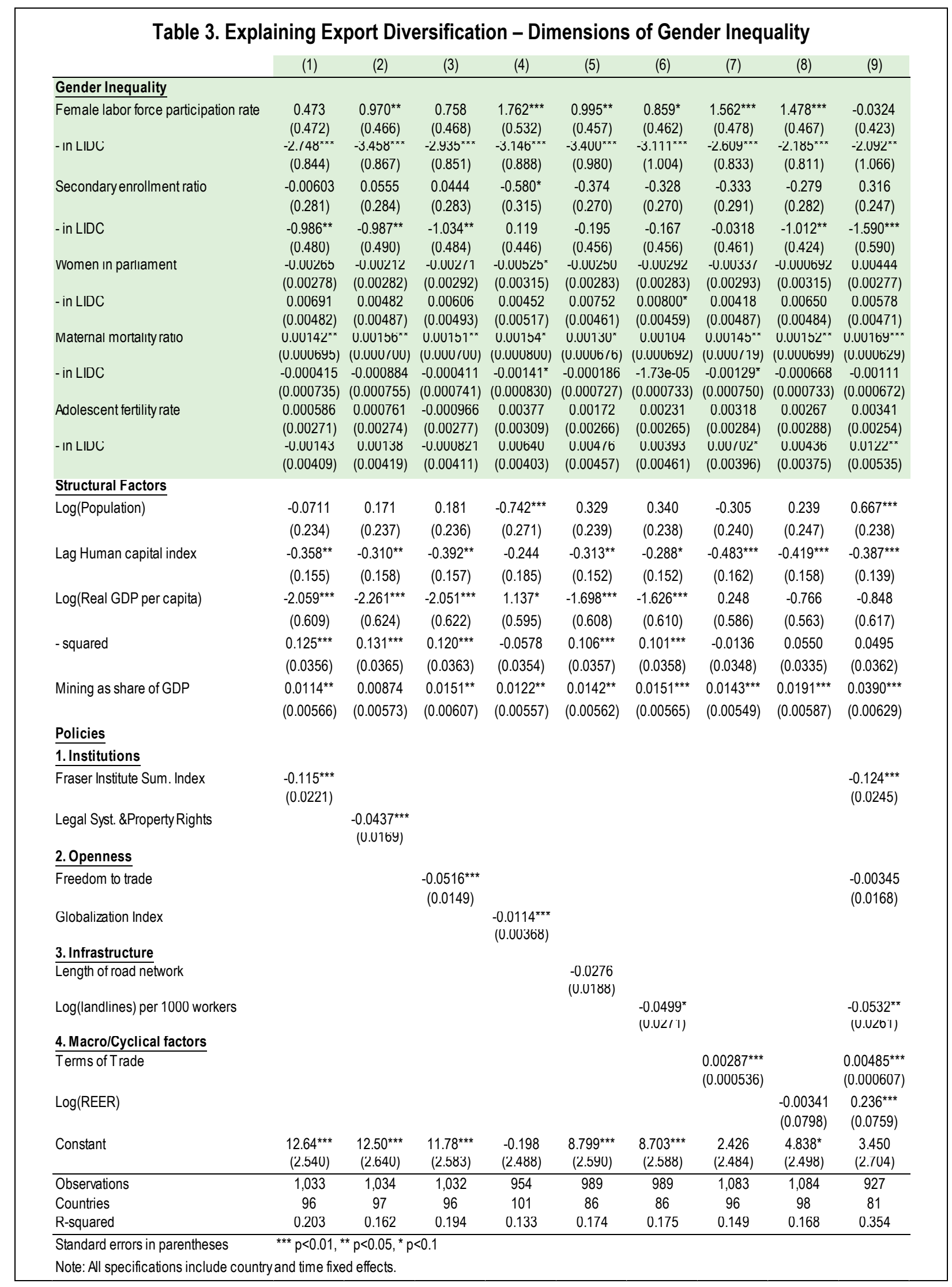




\begin{tabular}{|c|c|c|c|c|c|c|c|c|c|}
\hline \multicolumn{10}{|c|}{ Table 4. Explaining Output Diversification - Dimensions of Gender Inequality } \\
\hline & (1) & (2) & (3) & (4) & (5) & (6) & (7) & (8) & (9) \\
\hline \multicolumn{10}{|l|}{ Gender Inequality } \\
\hline Female labor force participation rate & $\begin{array}{c}0.0160 \\
(0.0449)\end{array}$ & $\begin{array}{c}0.0562 \\
(0.0446)\end{array}$ & $\begin{array}{c}0.0665 \\
(0.0642)\end{array}$ & $\begin{array}{l}-0.0181 \\
(0.0505)\end{array}$ & $\begin{array}{l}0.0776^{*} \\
(0.0469)\end{array}$ & $\begin{array}{c}0.0624 \\
(0.0474)\end{array}$ & $\begin{array}{c}0.0613 \\
(0.0543)\end{array}$ & $\begin{array}{c}0.0580 \\
(0.0681)\end{array}$ & $\begin{array}{c}0.0127 \\
(0.0704)\end{array}$ \\
\hline - in LIDC & $\begin{array}{c}0.0695 \\
(0.0810)\end{array}$ & $\begin{array}{c}0.0358 \\
(0.0821)\end{array}$ & $\begin{array}{l}-0.292^{\star *} \\
(0.123)\end{array}$ & $\begin{array}{r}-0.00734 \\
(0.0843)\end{array}$ & $\begin{array}{c}0.0568 \\
(0.0924)\end{array}$ & $\begin{array}{c}0.0749 \\
(0.0939)\end{array}$ & $\begin{array}{c}0.0384 \\
(0.0978)\end{array}$ & $\begin{array}{c}-0.421^{\text {***}} \\
(0.156)\end{array}$ & $\begin{array}{c}-0.342^{\star *} \\
(0.174)\end{array}$ \\
\hline Secondary enrollment ratıo & $\begin{array}{l}\text { U.124 } \\
\text { (U.U263) }\end{array}$ & $\begin{array}{l}\text { U.133 } \\
\text { (U.U265) }\end{array}$ & 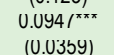 & $\begin{array}{l}U .11 y^{\pi \pi x} \\
(U .02 y 3)\end{array}$ & $\begin{array}{l}\text { U.11U } \\
(U . U 2 / 1)\end{array}$ & $\begin{array}{l}U .11 / /^{\pi \pi \pi} \\
(U . U 2 / 1)\end{array}$ & $\begin{array}{l}0.0922^{\pi \pi \pi} \\
\text { (U.U315) }\end{array}$ & $\begin{array}{l}0 . U / \zeta 1^{\pi x} \\
(U . U 3 / 1)\end{array}$ & $\begin{array}{c}0.0313 \\
(U .0384)\end{array}$ \\
\hline -in LIDC & $\begin{array}{l}-0.0407 \\
(0.0453)\end{array}$ & $\begin{array}{l}-0.0502 \\
(0.0458)\end{array}$ & $\begin{array}{c}-0.107^{*} \\
(0.0595)\end{array}$ & $\begin{array}{c}-0.0965^{* \star} \\
(0.0417)\end{array}$ & $\begin{array}{l}-0.0696 \\
(0.0439)\end{array}$ & $\begin{array}{l}-0.0695 \\
(0.0439)\end{array}$ & $\begin{array}{l}-0.0760^{*} \\
(0.0452)\end{array}$ & $\begin{array}{l}-0.0776 \\
(0.0740)\end{array}$ & $\begin{array}{c}-0.282^{* \star *} \\
(0.105)\end{array}$ \\
\hline Women in parliament & $\begin{array}{l}-0.000203 \\
(0.000260)\end{array}$ & $\begin{array}{l}-0.000462^{*} \\
(0.000277)\end{array}$ & $\begin{array}{l}-0.000449 \\
(0.000352)\end{array}$ & $\begin{array}{l}-0.000178 \\
(0.000295)\end{array}$ & $\begin{array}{c}-0.000573^{* *} \\
(0.000283)\end{array}$ & $\begin{array}{c}-0.000619^{* *} \\
(0.000284)\end{array}$ & $\begin{array}{l}-0.000456 \\
(0.000324)\end{array}$ & $\begin{array}{c}-0.000386 \\
(0.000360)\end{array}$ & $\begin{array}{l}-0.000523 \\
(0.000379)\end{array}$ \\
\hline - in LIDC & $\begin{array}{l}-0.000136 \\
(0.000458)\end{array}$ & $\begin{array}{c}3.47 \mathrm{e}-05 \\
(0.000470)\end{array}$ & $\begin{array}{c}0.000539 \\
(0.000696)\end{array}$ & $\begin{array}{c}7.31 \mathrm{e}-05 \\
(0.000473)\end{array}$ & $\begin{array}{c}6.11 \mathrm{e}-05 \\
(0.000439)\end{array}$ & $\begin{array}{c}0.000167 \\
(0.000440)\end{array}$ & $\begin{array}{c}0.000372 \\
(0.000531)\end{array}$ & $\begin{array}{l}0.000137 \\
(0.00102)\end{array}$ & $\begin{array}{l}-0.000579 \\
(0.00128)\end{array}$ \\
\hline Maternal mortality ratio & $\begin{array}{l}0.000162^{* \star} \\
(6.51 \mathrm{e}-05)\end{array}$ & $\begin{array}{c}0.000171^{* \star *} \\
(6.58 \mathrm{e}-05)\end{array}$ & $\begin{array}{c}6.44 \mathrm{e}-05 \\
(9.43 e-05)\end{array}$ & $\begin{array}{l}6.27 e-05 \\
(7.45 e-05)\end{array}$ & $\begin{array}{c}0.000203^{\star * \star} \\
(6.89 \mathrm{e}-05)\end{array}$ & $\begin{array}{l}0.000174^{* *} \\
(7.02 \mathrm{e}-05)\end{array}$ & $\begin{array}{c}0.000117 \\
(7.95 \mathrm{e}-05)\end{array}$ & $\begin{array}{c}5.40 \mathrm{e}-05 \\
(9.70 \mathrm{e}-05)\end{array}$ & $\begin{array}{c}1.97 e-07 \\
(9.69 e-05)\end{array}$ \\
\hline - in LIDC & $\begin{array}{l}-8.27 \mathrm{e}-05 \\
(6.94 \mathrm{e}-05)\end{array}$ & $\begin{array}{l}-7.99 \mathrm{e}-05 \\
\text { (1.02e-Ub) }\end{array}$ & $\begin{array}{c}4.73 \mathrm{e}-05 \\
(1.00 \mathrm{e}-04)\end{array}$ & $\begin{array}{l}7.38 \mathrm{e}-05 \\
(1.19 \mathrm{e}-0 \mathrm{u})\end{array}$ & $\begin{array}{l}-0.000136^{*} \\
(/ .44 \mathrm{e}-U b)\end{array}$ & $\begin{array}{l}-0.000115 \\
(1.52 \mathrm{e}-05)\end{array}$ & $\begin{array}{l}3.04 \mathrm{e}-05 \\
(8.34 \mathrm{e}-05)\end{array}$ & $\begin{array}{l}-1.43 \mathrm{e}-06 \\
\text { (0.000105) }\end{array}$ & $\begin{array}{c}7.79 \mathrm{e}-06 \\
(0.000122)\end{array}$ \\
\hline Adolescent fertility rate & $\begin{array}{c}0.000925^{\star \star \pi} \\
(0.000258)\end{array}$ & $\begin{array}{l}0.00101^{\star * \pi} \\
(0.000264)\end{array}$ & $\begin{array}{l}0.000931^{\star *} \\
(0.000373)\end{array}$ & $\begin{array}{c}0.000769^{\star \star \pi} \\
(0.000290)\end{array}$ & $\begin{array}{c}0.000327 \\
(0.000270)\end{array}$ & $\begin{array}{c}0.000428 \\
(0.000270)\end{array}$ & $\begin{array}{l}0.000535^{\star} \\
(0.000305)\end{array}$ & $\begin{array}{c}0.000401 \\
(0.000474)\end{array}$ & $\begin{array}{c}0.000758 \\
(0.000488)\end{array}$ \\
\hline - in LIDC & $\begin{array}{l}0.000974^{* *} \\
(0.00038 /)\end{array}$ & $\begin{array}{l}0.000993^{* x} \\
(0.000391)\end{array}$ & $\begin{array}{c}0.00119^{\star *} \\
(0.000 b 23)\end{array}$ & $\begin{array}{l}0.00110^{* \pi x} \\
(0.0003 / 8)\end{array}$ & $\begin{array}{l}0.00163^{\star \star * \pi} \\
(0.000443)\end{array}$ & $\begin{array}{l}0.00153^{* \pi x} \\
(0.000450)\end{array}$ & $\begin{array}{l}0.00132^{* \pi \times} \\
(0.000421)\end{array}$ & $\begin{array}{l}0.00181^{\star * \pi} \\
(0.000655)\end{array}$ & $\begin{array}{l}-0.000633 \\
(0.00104)\end{array}$ \\
\hline \multicolumn{10}{|l|}{ Structural Factors } \\
\hline Log(Population) & $\begin{array}{c}-0.0116 \\
(0.0224)\end{array}$ & $\begin{array}{r}-0.00569 \\
(0.0227)\end{array}$ & $\begin{array}{c}0.0546 \\
(0.0334)\end{array}$ & $\begin{array}{c}0.0336 \\
(0.0259)\end{array}$ & $\begin{array}{c}-0.00484 \\
(0.0244)\end{array}$ & $\begin{array}{c}-0.00776 \\
(0.0243)\end{array}$ & $\begin{array}{c}0.0438 \\
(0.0286)\end{array}$ & $\begin{array}{c}-0.0281 \\
(0.0396)\end{array}$ & $\begin{array}{c}-0.00629 \\
(0.0422)\end{array}$ \\
\hline Lag Human capital Index & $\begin{array}{c}0.0183 \\
(0.0148)\end{array}$ & $\begin{array}{c}0.0191 \\
(0.0150)\end{array}$ & $\begin{array}{c}0.0146 \\
(0.0221)\end{array}$ & $\begin{array}{c}0.0234 \\
(0.0176)\end{array}$ & $\begin{array}{c}\text { U.019y } \\
(0.0157)\end{array}$ & $\begin{array}{c}\text { U.U230 } \\
(0.0157)\end{array}$ & $\begin{array}{c}0.0158 \\
(0.0188)\end{array}$ & $\begin{array}{l}0.04 / y^{\star \pi} \\
(0.0239)\end{array}$ & $\begin{array}{l}0.045 y^{\pi} \\
(0.0239)\end{array}$ \\
\hline Log(Real GDP per capita) & $\begin{array}{l}-0.0755 \\
(0.0585)\end{array}$ & $\begin{array}{l}-0.0619 \\
(0.0602)\end{array}$ & $\begin{array}{l}-0.196^{* *} \\
(0.0801)\end{array}$ & $\begin{array}{c}-0.217^{\star * *} \\
(0.0566)\end{array}$ & $\begin{array}{l}-0.124^{\star *} \\
(0.0607)\end{array}$ & $\begin{array}{c}-0.115^{*} \\
(0.0613)\end{array}$ & $\begin{array}{c}-0.240^{\star * *} \\
(0.0691)\end{array}$ & $\begin{array}{l}0.0433 \\
(0.129)\end{array}$ & $\begin{array}{l}-0.243 \\
(0.152)\end{array}$ \\
\hline - squared & $\begin{array}{c}0.00239 \\
(0.00342)\end{array}$ & $\begin{array}{l}10.000941 \\
(0.00352)\end{array}$ & $\begin{array}{l}0.00921^{*} \\
(0.004 / 6)\end{array}$ & $\begin{array}{l}0.00980^{* * \pi} \\
(0.00333 /)\end{array}$ & $\begin{array}{c}0.00422 \\
(0.00356)\end{array}$ & $\begin{array}{c}0.00368 \\
(0.00360)\end{array}$ & $\begin{array}{l}0.0112^{* * \pi} \\
(0.00416)\end{array}$ & $\begin{array}{c}-0.00306 \\
(0.00 / 18)\end{array}$ & $\begin{array}{c}0.0141 \\
(0.0085 y)\end{array}$ \\
\hline Mining as share of GDP & $\begin{array}{c}0.000103 \\
(0.000544)\end{array}$ & $\begin{array}{c}-0.000482 \\
(0.000587)\end{array}$ & $\begin{array}{c}-0.00373^{\approx \pi x} \\
(0.000827)\end{array}$ & $\begin{array}{l}-9.53 \mathrm{e}-05 \\
(0.000510)\end{array}$ & $\begin{array}{l}0.00241^{* * *} \\
(0.000554)\end{array}$ & $\begin{array}{l}0.00252^{* * \pi} \\
(0.000562)\end{array}$ & $\begin{array}{c}0.000476 \\
(0.000556)\end{array}$ & $\begin{array}{c}-0.00552^{* * \pi} \\
(0.00123)\end{array}$ & $\begin{array}{c}-0.00855^{\star \star \pi} \\
(0.00131)\end{array}$ \\
\hline \multicolumn{10}{|l|}{ Policies } \\
\hline \multicolumn{10}{|l|}{$\overline{1 . \text { Institutions }}$} \\
\hline$\overline{\text { Fraser Institute }}$ Sum. Index & $\begin{array}{l}-0.0107^{\star * *} \\
(0.00212)\end{array}$ & & & & & & & & $\begin{array}{l}-0.00724^{\star *} \\
(0.00341)\end{array}$ \\
\hline \multicolumn{10}{|l|}{ 2. Openness } \\
\hline Freedom to trade & & $\begin{array}{l}-0.00251^{*} \\
(0.00144)\end{array}$ & & & & & & & \\
\hline Average Tariff Rates & & & $\begin{array}{c}0.0636^{* * *} \\
(0.0183)\end{array}$ & & & & & & $\begin{array}{l}0.143^{* * *} \\
(0.0251)\end{array}$ \\
\hline Globalization Index & & & & $\begin{array}{l}-0.00121^{* * *} \\
(0.000351)\end{array}$ & & & & & \\
\hline \multicolumn{10}{|l|}{ 3. Infrastructure/lnvestment } \\
\hline Length of road network & & & & & $\begin{array}{c}-0.00474^{\star \star} \\
(0.00190)\end{array}$ & & & & \\
\hline Log(landlines) per 1000 workers & & & & & & $\begin{array}{c}-0.00573^{* *} \\
(0.00267)\end{array}$ & & & $\begin{array}{c}-0.00403 \\
(0.00390)\end{array}$ \\
\hline Investment per worker & & & & & & & $\begin{array}{l}-1.67 \mathrm{e}-06^{*} \\
(y .5 y e-0 /)\end{array}$ & & $\begin{array}{c}-5.39 \mathrm{e}-06^{\star * *} \\
(1.41 \mathrm{e}-\mathrm{Ub})\end{array}$ \\
\hline \multicolumn{10}{|l|}{ 4. Financial Development } \\
\hline Financial reform index & & & & & & & & $-0.115^{\star \star *}$ & $-0.0630^{\star * *}$ \\
\hline Constant & $\begin{array}{l}0.541^{\pi \pi} \\
(0.245)\end{array}$ & $\begin{array}{l}0.4 b 1^{\pi} \\
(0.251)\end{array}$ & $\begin{array}{l}0.933^{\pi \pi x} \\
(0.330)\end{array}$ & $\begin{array}{l}1.10 y^{\pi \times \pi} \\
(0.236)\end{array}$ & $\begin{array}{c}U . / 1 y^{\pi \pi \pi} \\
(0.257)\end{array}$ & $\begin{array}{l}U . / 1 /^{\pi \pi x} \\
(0.258)\end{array}$ & $\begin{array}{l}1.124^{\pi \times \pi} \\
(0.291)\end{array}$ & $\begin{array}{c}(0.0201) \\
0.138 \\
(0.554)\end{array}$ & $\begin{array}{c}(0.0226) \\
1.38 y^{\pi \pi} \\
(0.656)\end{array}$ \\
\hline Observations & 1,063 & 1,062 & 681 & 987 & 1,014 & 1,014 & 942 & 552 & 485 \\
\hline Countries & 98 & 98 & 95 & 103 & 87 & 87 & 104 & 73 & 65 \\
\hline R-squared & 0.245 & 0.229 & 0.231 & 0.330 & 0.259 & 0.258 & 0.294 & 0.276 & 0.341 \\
\hline
\end{tabular}




\begin{tabular}{|c|c|c|c|c|c|}
\hline \multicolumn{6}{|c|}{ Table 5. Explaining Diversification - Instrumental Variable GMM } \\
\hline \multicolumn{3}{|c|}{ Export Diversification } & \multicolumn{3}{|c|}{ Output Diversification } \\
\hline & (1) & (2) & & (1) & (2) \\
\hline \multirow[t]{2}{*}{ GII Index } & $5.785^{\star \star \star}$ & $3.534^{\star *}$ & GII Index & $1.778^{\star \star \star}$ & $0.153^{\star * \star}$ \\
\hline & $(1.942)$ & (1.739) & & $(0.361)$ & $(0.0387)$ \\
\hline \multirow[t]{2}{*}{ Log(Population) } & $-0.976^{\star \star *}$ & -0.252 & Log(Population) & $-0.0830^{* *}$ & $-0.134^{\star * \star}$ \\
\hline & $(0.214)$ & $(0.271)$ & & $(0.0396)$ & $(0.0230)$ \\
\hline \multirow[t]{2}{*}{ Lag Human capital index } & 0.0251 & $0.420^{* * *}$ & Lag Human capital index & $0.131^{\star * *}$ & -0.00844 \\
\hline & $(0.196)$ & $(0.162)$ & & $(0.0321)$ & $(0.0116)$ \\
\hline \multirow[t]{2}{*}{ Log(GDP per capita) } & $-1.307^{\star * *}$ & $-0.666^{\star}$ & Log(GDP per capita) & $-0.390^{\star \star *}$ & $-0.222^{\star \star *}$ \\
\hline & $(0.337)$ & $(0.343)$ & & $(0.0726)$ & $(0.0809)$ \\
\hline \multirow[t]{2}{*}{ - squared } & $0.0931^{* * *}$ & $0.0360^{*}$ & - squared & $0.0230^{* * *}$ & $0.0141^{* * *}$ \\
\hline & $(0.0201)$ & $(0.0196)$ & & $(0.00446)$ & $(0.00473)$ \\
\hline \multirow[t]{2}{*}{ Mining as share of GDP } & $0.0318^{* * *}$ & 0.0105 & Mining as share of GDP & 0.00129 & $-8.56 e-05$ \\
\hline & $(0.00710)$ & $(0.00659)$ & & $(0.00126)$ & $(0.000944)$ \\
\hline \multirow{2}{*}{\multicolumn{2}{|c|}{ Fraser Institute Sum. Index }} & -0.0498 & Fraser Institute Sum. Index & & $-0.0114^{\star * *}$ \\
\hline & & $(0.0363)$ & & & $(0.00169)$ \\
\hline \multirow[t]{2}{*}{ Freedom to trade } & & $-0.0405^{\star \star *}$ & Average Tariff Rates & & $0.0361^{\star \star \star}$ \\
\hline & & $(0.0141)$ & & & $(0.0105)$ \\
\hline \multirow[t]{2}{*}{ Log(landlines) per 1000 workers } & & $-0.0919 * * *$ & \multirow{2}{*}{\multicolumn{2}{|c|}{ Log(landlines) per 1000 workers }} & -0.00201 \\
\hline & & $(0.0281)$ & & & $(0.00190)$ \\
\hline \multirow[t]{2}{*}{ Terms of Trade } & & $0.00427^{* * *}$ & Investment per worker & & $-5.89 e-06^{* * *}$ \\
\hline & & $(0.000609)$ & & & $(1.02 \mathrm{e}-06)$ \\
\hline \multirow[t]{2}{*}{$\log (R E E R)$} & & $0.301^{* * *}$ & Financial reform index & & -0.00467 \\
\hline & & $(0.0588)$ & & & $(0.0124)$ \\
\hline \multirow[t]{2}{*}{ Constant } & $5.515^{\star * *}$ & 3.438 & Constant & $0.923^{\star * \star}$ & $1.578^{\star \star \star}$ \\
\hline & $(2.046)$ & $(2.466)$ & & $(0.329)$ & $(0.354)$ \\
\hline Observations & 1,552 & 1,204 & Observations & 1,554 & 833 \\
\hline P-value of Hansen J statistic & 0.296 & 0.248 & P-value of Hansen J statistic & 0.548 & 0.276 \\
\hline Instrument F-test & 13.27 & 12.85 & Instrument F-test & 16.28 & 33.44 \\
\hline \multicolumn{3}{|l|}{ Standard errors in parentheses } & \multicolumn{3}{|l|}{ Standard errors in parentheses } \\
\hline \multicolumn{3}{|l|}{${ }^{* * *} p<0.01,{ }^{* *} p<0.05,{ }^{*} p<0.1$} & \multicolumn{3}{|l|}{${ }^{* * *} p<0.01,{ }^{* *} p<0.05,{ }^{*} p<0.1$} \\
\hline \multicolumn{3}{|c|}{$\begin{array}{l}\text { Note: All specifications include country and time fixed } \\
\text { effects. }\end{array}$} & \multicolumn{3}{|c|}{$\begin{array}{l}\text { Note: All specifications include country and time fixed } \\
\text { effects. Lesotho and Mauritania are dropped from the } \\
\text { estimation due to insufficient observations. }\end{array}$} \\
\hline
\end{tabular}




\section{Conclusions}

21. This paper presents, to the best of our knowledge, the first empirical evidence that gender inequality impacts both export and output diversification. Using a multidimensional index to capture gender inequality, as well as individual indicators of gender inequality, we show that gender inequality, both in outcomes and in opportunities, negatively impacts export and output diversification in low-income and developing countries. Our paper provides evidence that both gender equity in opportunities as well as outcomes matter for economic diversification. In particular, we show that both gender inequalities in opportunities, such as education, and lower female labor force participation, are negatively associated with diversification. The former supports the hypothesis of inequality constraining the level of human capital which limits diversification - and could be tested along generalized inequality of opportunity in future research. The latter supports the theory of an inefficient allocation of resources leading to suboptimal creation of ideas and development of sectors.

22. Our empirical work provides support for causality between gender inequality and diversification. We separate the effect of gender inequality on diversification from the reverse effect of diversification on gender inequality, due to our empirical estimation strategy which uses the country-specific de jure laws and regulations as instruments for gender inequality. These legal restrictions, such as restrictions to the right to be the head of a household, skew the efficient allocation of resources by impeding women's economic participation and preventing households from giving the same opportunities to daughters and sons.

23. By linking gender inequality to lower economic diversification-which is widely acknowledged to be a source of sustainable growth-we highlight a new channel through which gender equality boosts growth. 


\section{References}

Aghion, P. and P. Howitt. 2006. "Joseph Schumpeter Lecture-Appropriate Growth Policy: A Unifying Framework." Journal of the European Economic Association 4(2-3): 269-314.

Agenor, P., O. Canuto, and L. da Silva. 2010. “On Gender and Growth: The Role of Intergenerational Health Externalities and Women's Occupational Constraints." World Bank Policy Research Working Paper 5492.

Akbulut, R. 2011. "Sectoral changes and the increase in women's labor force participation." Macroeconomic Dynamics 15(2): 240-264.

Alesina, A.F., P. Giuliano, and N. Nunn. 2011. "On the origins of gender roles: Women and the plough.” National Bureau of Economic Research Working Paper w17098.

Amin, M. and A. Islam. 2014. "Are There More Female Managers in the Retail Sector? Evidence from Survey Data in Developing Countries." World Bank Policy Research Working Paper 6843.

Amin, M., V. Kuntchev, and M. Schmidt. 2015. "Gender Inequality and Growth: The Case of Rich vs. Poor Countries”. World Bank Policy Research Working Paper 7172.

Bal-Gunduz, Y., E. Dabla-Norris, and C. Intal. 2015. "What Drives Economic Diversification?” International Monetary Fund Working Paper.

Bandiera, O. and A. Natraj. 2013. "Does gender inequality hinder development and economic growth? Evidence and policy implications." The World Bank Research Observer.

Barro, R. J. and J. Lee. 1994. "Sources of economic growth." Carnegie-Rochester conference series on public policy 40: 1-46.

Barro, R. J. and X. Sala-i-Martin. 1995. "Economic Growth.” McGraw Hill.

Berge, K. and A. Wood.1994. "Does educating girls improve export opportunities?" Working paper.

Cadot, O., C. Carrere, and V. Strauss-Kahn. 2011. "Export Diversification: What's Behind the Hump?" Review of Economics and Statistics 93: 590-605.

Cagatay, N., D. Elson, and C. Grown. 1995. “Introduction.” World Development, Special Issue on Gender, Adjustment and Macroeconomics, 23(11): 1827-36.

Cavalcanti, T. and J. Tavares. 2007. "The Output Cost of Gender Discrimination: A Model Based Macroeconomic Estimate," Universidade Nova de Lisboa and Center for Economic Policy Research. Mimeo.

Cavalcanti, T. and J. Tavares. 2016. "The Output Cost of Gender Discrimination: A Model Based Macroeconomic Estimate.” The Economic Journal. Vol. 126. Issue 590, p. 109-134. 
Christiansen, L., H. Lin, J. Pereira, P. Topalova, R. Turk, and P. Koeva Brooks. 2016 a. "Unlocking Female Employment Potential in Europe. Drivers and Benefits," IMF European Department and Strategy, Policy, Review Department. Departmental Paper. Washington, DC. International Monetary Fund.

Christiansen, L., H. Lin, J. Pereira, P. Topalova, R. Turk. 2016b. "Gender Diversity in Senior Positions and Firm Performance: Evidence from Europe," IMF Working Paper 16/50. Washington DC, International Monetary Fund.

Cuberes, D., and M. Teignier. 2012. "Gender Gaps in the Labor Market and Aggregate Productivity.” Sheffield Economic Research Paper SERP 2012017.

Cuberes, D., and M. Teignier. 2014a. "Aggregate Costs of Gender Gaps in the Labor Market: A Quantitative Estimate.” UB Economics Working Paper 2014/308.

Cuberes, D. and M. Teignier. 2014b. "Gender Inequality and Economic Growth: A Critical Review.” Journal of International Development 26: 260-276.

Dabla-Norris, E., A. Thomas, R. Garcia-Verdu, and Y. Chen. 2013. "Benchmarking Structural Transformation Across the World," IMF Working Paper 13/176.

Deere, C. D., A. D. Oduro, H. Swaminathan, and C. Doss. 2013. "Property rights and the gender distribution of wealth in Ecuador, Ghana and India." Journal of Economic Inequality 11: 249-265.

Demirgüç-Kunt, A., L. Klapper, and D. Singer. 2013. "Financial inclusion and legal discrimination against women : evidence from developing countries." World Bank Policy Research Working Paper 6416.

Doepke, M. and M. Tertilt. 2008. "Women's Liberation: What's in it for Men?" National Bureau of Economic Research Working Paper 13919.

Dollar, D. and R. Gatti. 1999. "Gender inequality, income, and growth: are good times good for women?” Vol. 1. Washington, DC: Development Research Group, The World Bank.

Duflo, E. 2012. "Women Empowerment and Economic Development," Journal of Economic Literature 50(4): 1051-1079.

Elborgh-Woytek, K., M. Newiak, K. Kochhar, S. Fabrizio, K. Kpodar, P. Wingender, B. Clements, and G. Schwartz. 2013. "Women, Work, and the Economy: Macroeconomic Gains from Gender Equity.” Staff Discussion Note, SDN/13/10, (Washington: International Monetary Fund).

Engelbrecht, H.J. 1997. "International R\&D spillovers, human capital and productivity in OECD economies: An empirical investigation." European Economic Review 41(8): 14791488. 
Esteve-Volart, B. 2004. "Gender Discrimination and Growth: Theory and Evidence from India.” DEDPS 42, London: London School of Economics.

Fernandez, R. 2007. "Alfred Marshall lecture women, work, and culture." Journal of the European Economic Association 5(2-3): 305-332.

Forbes, K. J. 1998. "A reassessment of the relationship between inequality and growth." Massachusetts Institute of Technology Working Paper.

Galor, O. and Weil, D. 1996. "The Gender Gap, Fertility, and Growth.” American Economic Review 85(3): 374-87.

Goldin, C. 1994. "The U-Shaped Female Labor Force Function in Economic Development and Economic History." National Bureau of Economic Research Working Paper 4707.

Gonzales, C., S. Jain-Chandra, K. Kochhar, and M. Newiak. 2015a. "Fair Play: More Equal Laws Boost Female Labor Force Participation.” International Monetary Fund Staff Discussion Note 15/02.

Gonzales, C., S. Jain-Chandra, K. Kochhar, M. Newiak, and T. Zeinullayev, 2015b. Catalyst for Change: Empowering Women and Tackling Income Inequality. Washington, DC: IMF.

Hakura, D., M. Hussain, M. Newiak, V. Thakoor, and F. Yang, 2016, "Inequality, Gender Gaps and Economic Growth: Comparative Evidence for Sub-Saharan Africa". IMF Working Paper No. 16/111.

Hill, M. A, and E. King. 1995. "Women's education and economic well-being." Feminist Economics 1(2): 21-46.

Imbs, J. and R. Wacziarg. 2003. "Stages of Diversification." American Economic Review 93(1): 63-86.

IMF. 2014a. "Sustaining Long-Run Growth and Macro Stability in Low-income Countries: The Role of Structural Transformation and Diversification - Background Notes." IMF Policy Paper.

IMF. 2014b. "Sustaining Long-run Growth and Macroeconomic Stability in Low-income Countries - The Role of Structural Transformation and Diversification." IMF Policy Paper.

IMF. 2016. "Time for a Policy Reset". Regional Economic Outlook: Sub-Saharan African" April 2016. (Washington: International Monetary Fund).

Klasen, S. 1999. "Does Gender Inequality Reduce Growth and Development? Evidence from Cross-Country Regressions.” World Bank Policy Research Report Background Paper No.7.

Klasen, S. and Lamanna, F. 2009. "The Impact of Gender Inequality in Education and Employment on Economic Growth: New Evidence for a Panel of Countries." Feminist Economics 15(3): 91-132. 
Knowles, S., P. K. Lorgelly, and P. D. Owen. 2002. "Are educational gender gaps a brake on economic development? Some cross-country empirical evidence." Oxford Economic Papers 54(1): 118-149.

Koren, M. and S. Tenreyro. 2007. "Volatility and Development." Quarterly Journal of Economics 122: 243-87.

Lagerlöf, N. P. 2003. "Gender equality and long-run growth." Journal of Economic Growth 8(4): 403-426.

Lorgelly, P. K. and P. D. Owen. 1999. "The effect of female and male schooling on economic growth in the Barro-Lee model." Empirical Economics 24(3): 537-557.

Mobarak, A. M. 2005. "Democracy, Volatility, and Economic Development." Review of Economics and Statistics 87: 348-61.

Moore, W. and C. Walkes. 2010. "Does Industrial Concentration Impact on the Relationship between Policies and Volatility?" International Review of Applied Economics 24: 179-202.

Ngai, R. and B. Petrongolo. 2014. "Gender gaps and the rise of the service economy." Institute for the Study of Labor (IZA) Discussion Paper No. 8134.

Olivetti, C. and B. Petrongolo. 2014. "Gender gaps across countries and skills: Demand, supply and the industry structure." Review of Economic Dynamics 17(4): 842-859.

Papageorgiou, C. and N. Spatafora. 2012. "Economic Diversification in LICs: Stylized Facts and Macroeconomic Implications." IMF Staff Discussion Note 12/13.

Quisumbing, A. R. and L. Pandolfelli. 2010. "Promising approaches to address the needs of poor female farmers: Resources, constraints, and interventions." World Development 38(4): 581-592.

Razavi, S. 2003. "Introduction: Agrarian change, gender and land rights." Journal of Agrarian Change 3(1-2): 2-32.

Rendall, M. 2013. "Structural change in developing countries: has it decreased gender inequality?" World Development 45: 1-16.

Schober, T. and R. Winter-Ebmer. 2011. "Gender Wage Inequality and Economic Growth: Is There Really a Puzzle? — A Comment." World Development 39(8): 1476-1484.

Seguino, S. 2000. "Gender Inequality and Economic Growth: A Cross Country Analysis." World Development 28(7): 1211-30.

Seguino, S. 2010. "Gender, Distribution and Balance of Payments Constrained Growth in Developing Countries.” Review of Political Economy 22(3): 373-404. 
Singer, H. 1950. "US Foreign Investment in Underdeveloped Areas: The Distribution of Gains between Investing and Borrowing Countries." American Economic Review 40: 47385.

Stotsky, J. 2006. “Gender and Its Relevance to Macroeconomic Policy: A Survey,” IMF Working Paper.

Stotsky, J., S. Shibuya, L. Kolovich, and S. Kebhaj. 2016. “Trends in Women's Development and Gender Equality.” IMF Working Paper 16/21.

Svirydzenka, K. and M. Petri. 2014. "Mauritius: The Drivers of Growth - Can the Past be Extended?” IMF Working Paper 14/134.

Tzannatos, Z. 1999. "Women and labor market changes in the global economy: growth helps, inequalities hurt and public policy matters." World Development 27(3): 551-569.

World Bank. 2012. "World Development Report: Gender Equality and Development." World Bank.

World Bank and International Finance Corporation (IFC). 2013. "Women, Business, and the Law 2014. Removing Restrictions to Enhance Gender Equality." Washington: World Bank and IFC.

World Bank Group. 2015. "Women, Business and the Law 2016: Getting to Equal." Washington, DC: World Bank. 


\section{Annex I: Summary Statistics}

\begin{tabular}{|c|c|c|c|c|c|c|c|c|c|c|c|}
\hline \multicolumn{12}{|c|}{ Table A1. Key Variables and Summary Statistics } \\
\hline \multirow[b]{3}{*}{ Variable } & \multirow[b]{3}{*}{ Source } & \multicolumn{5}{|c|}{ Full Sample } & \multicolumn{5}{|c|}{ LIDC } \\
\hline & & & & Std. & & & & & Std. & & \\
\hline & & Obs & Mean & Dev. & Min & Max & Obs & Mean & Dev. & Min & Max \\
\hline Export Diversification Theil & IMF Diversification Toolkit & 6378 & 3.5 & 1.2 & 1.0 & 6.4 & 2159 & 4.2 & 0.9 & 1.8 & 6.4 \\
\hline Output Diversification Theil & IMF Diversification Toolkit & 7065 & 0.3 & 0.2 & 0.0 & 1.7 & 2259 & 0.3 & 0.2 & 0.0 & 1.6 \\
\hline Log(GDP per capita) & WEO & 6141 & 8.5 & 1.2 & 5.2 & 11.7 & 1910 & 7.2 & 0.5 & 5.2 & 8.8 \\
\hline Log(Population) & PWT 8.1 & 6141 & 1.7 & 1.9 & -3.2 & 7.2 & 1910 & 1.8 & 1.4 & -2.6 & 5.1 \\
\hline Human capital index (5-year lag) & PWT 8.1/ Barro Lee & 4385 & 2.1 & 0.6 & 1.0 & 3.6 & 1289 & 1.6 & 0.4 & 1.0 & 2.9 \\
\hline Mining as share of GDP & IMF Jobs and Income Surveillance toolkit & 4831 & 21.0 & 11.6 & 0.8 & 85.6 & 1865 & 17.7 & 11.6 & 0.8 & 75.9 \\
\hline GII Index & IMF GDI GII database & 2580 & 0.5 & 0.2 & 0.0 & 0.8 & 774 & 0.6 & 0.1 & 0.3 & 0.8 \\
\hline Ratio of female tertiary teachers & WDI & 2105 & 0.3 & 0.1 & 0.0 & 0.8 & 521 & 0.2 & 0.1 & 0.0 & 0.8 \\
\hline Unmarried women; equal property rights & Women, Business, and the Law & 3707 & 0.9 & 0.3 & 0.0 & 1.0 & 1470 & 0.9 & 0.3 & 0.0 & 1.0 \\
\hline Married women; equal property rights & Women, Business, and the Law & 3688 & 0.8 & 0.4 & 0.0 & 1.0 & 1431 & 0.7 & 0.5 & 0.0 & 1.0 \\
\hline Married women; head household & Women, Business, and the Law & 3723 & 0.6 & 0.5 & 0.0 & 1.0 & 1466 & 0.5 & 0.5 & 0.0 & 1.0 \\
\hline Married women; legal proceedings & Women, Business, and the Law & 3763 & 0.9 & 0.3 & 0.0 & 1.0 & 1506 & 0.8 & 0.4 & 0.0 & 1.0 \\
\hline Married women; bank account & Women, Business, and the Law & 3742 & 0.9 & 0.3 & 0.0 & 1.0 & 1490 & 0.8 & 0.4 & 0.0 & 1.0 \\
\hline Equal inheritance, sons and daughters & Women, Business, and the Law & 3688 & 0.7 & 0.5 & 0.0 & 1.0 & 1431 & 0.6 & 0.5 & 0.0 & 1.0 \\
\hline Joint titling of property & Women, Business, and the Law & 3582 & 0.4 & 0.5 & 0.0 & 1.0 & 1354 & 0.4 & 0.5 & 0.0 & 1.0 \\
\hline Full community marital property regime & Women, Business, and the Law & 3589 & 0.1 & 0.2 & 0.0 & 1.0 & 1351 & 0.0 & 0.2 & 0.0 & 1.0 \\
\hline Partial community marital property regime & $\epsilon$ Women, Business, and the Law & 3589 & 0.4 & 0.5 & 0.0 & 1.0 & 1351 & 0.3 & 0.5 & 0.0 & 1.0 \\
\hline Separate property marital property regime & $\epsilon$ Women, Business, and the Law & 3589 & 0.4 & 0.5 & 0.0 & 1.0 & 1351 & 0.5 & 0.5 & 0.0 & 1.0 \\
\hline Guaranteed equity & Women, Business, and the Law & 3734 & 0.9 & 0.3 & 0.0 & 1.0 & 1501 & 0.9 & 0.3 & 0.0 & 1.0 \\
\hline Nondiscrimination clause & Women, Business, and the Law & 3734 & 0.4 & 0.5 & 0.0 & 1.0 & 1501 & 0.4 & 0.5 & 0.0 & 1.0 \\
\hline Valid customary law & Women, Business, and the Law & 3734 & 0.3 & 0.5 & 0.0 & 1.0 & 1501 & 0.5 & 0.5 & 0.0 & 1.0 \\
\hline
\end{tabular}




\begin{tabular}{|c|c|c|c|c|c|c|c|c|c|c|c|}
\hline \multirow[b]{4}{*}{ Variable } & \multicolumn{11}{|c|}{ Table A1. Key Variables and Summary Statistics (continued) } \\
\hline & \multirow[b]{3}{*}{ Source } & \multicolumn{5}{|c|}{ Full Sample } & \multicolumn{5}{|c|}{ LIDC } \\
\hline & & \multicolumn{5}{|c|}{ Std. } & \multicolumn{5}{|c|}{ Std. } \\
\hline & & Obs & Mean & Dev. & Min & Max & Obs & Mean & Dev. & Min & Max \\
\hline Female labor force participation rate & WDI & 3591 & 0.5 & 0.2 & 0.1 & 0.9 & 1197 & 0.6 & 0.2 & 0.1 & 0.9 \\
\hline Secondary enrollment ratio & WDI & 4371 & 0.9 & 0.3 & 0.0 & 3.1 & 1230 & 0.7 & 0.3 & 0.0 & 2.1 \\
\hline Women in parliament & WDI & 2425 & 14.1 & 9.9 & 0.0 & 56.3 & 753 & 12.0 & 9.1 & 0.0 & 56.3 \\
\hline Maternal mortality ratio & WDI & 3591 & 272.0 & 374.7 & 3.0 & 2900 & 1218 & 623.4 & 422.8 & 29.0 & 2900.0 \\
\hline Adolescent fertility rate & WDI & 3696 & 65.0 & 49.3 & 3.1 & 229 & 1218 & 106.6 & 48.3 & 18.0 & 222.4 \\
\hline Fraser Institute Summary Index & Fraser Institute & 3655 & 5.9 & 1.4 & 2.0 & 9.2 & 1100 & 5.1 & 1.1 & 2.0 & 7.5 \\
\hline Legal system and property rights & Fraser Institute & 3509 & 5.3 & 1.9 & 1.1 & 9.6 & 5989 & 4.0 & 1.1 & 1.6 & 6.8 \\
\hline Freedom to trade & Fraser Institute & 3820 & 5.8 & 2.4 & 0.0 & 10.0 & 1215 & 4.3 & 2.1 & 0.0 & 8.8 \\
\hline Globalization index & KOF Index of Globalization & 4451 & 46.3 & 19.2 & 9.6 & 92.9 & 1728 & 31.4 & 10.2 & 9.6 & 63.1 \\
\hline Length of road network & Calderon-Serven database & 3755 & -1.2 & 1.4 & -5.2 & 1.6 & 51043 & -2.0 & 1.4 & -5.2 & 0.0 \\
\hline Log(Landlines per 1000 workers) & Calderon-Serven database & 3765 & 3.7 & 2.0 & -0.6 & 7.2 & 1043 & 1.8 & 1.1 & -0.6 & 5.2 \\
\hline Terms of Trade & WEO & 4334 & 109.7 & 48.7 & 5.5 & 602.9 & 1477 & 124.5 & 69.5 & 5.5 & 602.9 \\
\hline $\log ($ REER) & IFS & 3350 & 4.7 & 0.7 & 0.7 & 15.3 & 1171 & 4.9 & 1.0 & 0.7 & 15.3 \\
\hline Average Tariff Rates & Trade Index & 3194 & 0.7 & 0.2 & 0.0 & 1.0 & 999 & 0.7 & 0.2 & 0.0 & 1.0 \\
\hline Investment per worker & PWT & 4012 & 4589 & 5362 & -832 & 46086 & 51500 & 538 & 555 & -832 & 5208 \\
\hline Financial reform index & IMF Index of Financial reform & 2527 & 0.5 & 0.3 & 0.0 & 1.0 & 558 & 0.3 & 0.2 & 0.0 & 0.9 \\
\hline Gini index & WDI & 1035 & 40.7 & 10.3 & 16.2 & 99.9 & 233 & 43.0 & 9.1 & 25.9 & 69.5 \\
\hline Income ratio (top 20\%/bottom 20\%) & WDI & 1034 & 10.5 & 11.6 & 2.2 & 278.2 & 233 & 12.6 & 20.0 & 3.7 & 278.2 \\
\hline Agriculture, value added (\% of GDP) & WDI & 5099 & 19.0 & 15.5 & 0.0 & 74.3 & 31806 & 33.5 & 13.6 & 3.1 & 74.3 \\
\hline Rural population & WDI & 7044 & 50.9 & 24.8 & 0.0 & 97.2 & 2259 & 71.3 & 14.8 & 23.0 & 97.2 \\
\hline Fuel exports & WDI & 4516 & 16.2 & 29.1 & 0.0 & 359.3 & 1025 & 13.2 & 30.1 & 0.0 & 359.3 \\
\hline Domestic credit to private sector & WDI & 5731 & 37.8 & 35.8 & 0.1 & 312.2 & 1781 & 15.3 & 11.5 & 0.2 & 114.7 \\
\hline Real GDP per capita growth rate & World Economic Outlook & 5981 & 0.0 & 0.1 & -1.1 & 1.0 & 1861 & 0.0 & 0.1 & -0.7 & 0.7 \\
\hline
\end{tabular}




\section{Annex II: Country Sample}

\section{Non-LIDC Countries}

Albania, Argentina, Armenia, Australia, Austria, Belgium, Brazil, Bulgaria, Canada, Chile, China, Colombia, Costa Rica, Croatia. Denmark, Dominican Republic, Ecuador, Arab, Republic of Egypt, El Salvador, Estonia, Finland, France, Germany, Greece, Guatemala, Hungary, India, Indonesia, Islamic Republic of Iran, Iraq, Ireland, Israel, Italy, Jamaica, Japan, Jordan, Kazakhstan, Latvia, Lithuania, Malaysia, Mexico, Morocco, Namibia* Netherlands, New Zealand, Norway, Pakistan, Panama, Paraguay, Peru, Philippines, Poland, Portugal, Romania, Saudi Arabia, Singapore, Slovak Republic, Slovenia, South Africa, Spain, Sri Lanka, Sweden, Switzerland, Syrian Arab Republic, Thailand, Tunisia, Turkey, Ukraine, United Kingdom, United States, Uruguay, Venezuela

\section{LIDC Countries}

Bangladesh, Benin, Bolivia, Burundi, Cambodia, Cameroon, Central African Republic, Democratic Republic of Congo, Republic of Congo, Côte d'Ivoire, Ghana, Honduras, Kenya, Kyrgyz Republic, People's Democratic Republic of Lao, Lesotho*, Liberia, Malawi, Mali, Mauritania, Moldova, Mongolia, Mozambique, Nepal, Niger, Rwanda, Senegal, Sierra

Leone, Sudan, Tajikistan, Tanzania, Togo, Uganda, Republic of Yemen, Zambia, Zimbabwe

* Available for output diversification only. 